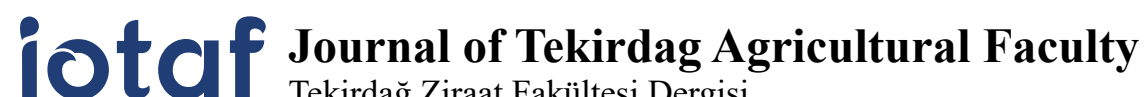 \\ Tekirdağ Ziraat Fakültesi Dergisi
}

Ocak/January 2019, 16(1)

Başvuru/Received: 28/02/17

Kabul/Accepted: $23 / 09 / 18$

DOI: $10.33462 /$ jotaf.399858

\section{Ganos Dağları Doğal Florasında Bulunan Kültür Asmalarının (Vitis vinifera L.) Moleküler ve Ampelografik Karakterizasyonu}

\author{
Molecular and Ampelographic Characterization of Grapevine (Vitis vinifera L.) Genetic \\ Materials Collected in Natural Flora of Ganos Mountains
}

\author{
Elman BAHAR ${ }^{1}$, İlknur KORKUTAL ${ }^{1}$, Nihan ŞAHİN ${ }^{1}$, Fatma Seren SAĞIR ${ }^{1}$, Demir KÖK ${ }^{1}$, \\ Onur ERGÖNÜL ${ }^{2}$, Tamer UYSAL ${ }^{2}$, Zeliha Orhan ÖZALP²
}

\begin{abstract}
Öz
Bu çalışma, Trakya Bölgesi Ganos (Işıklar) Dağları doğal florasına adapte olmuş ve varlığını sürdüren Vitis vinifera L. asma formlarına ait popülasyonların moleküler ve morfolojik karakterizasyonlarının belirlenmesi amacıyla yapılmıştır. DNA izolasyonları için kullanılan materyaller 2014 ve 2016 yılları Mayıs, Haziran, Temmuz aylarında dağların kuzey ve güney yamaçlarından 7 farklı alandan toplanmıştır. 2014 yılında yapılmış olan sörvey çalışmalarında belirlenen 103 örnekten, salkım gösteren 34 tanesinden 2016 yılında materyal alınmış ve moleküler karakterizasyonları yapılmıştır. Genotiplerin ampelografik ve moleküler özellikler açısından genel olarak birbirlerinden farklı olduğu ve 5 ayrı küme oluşturduğu belirlenmiştir. 34 genotipin moleküler karakterizasyonunda iki temel bileşene göre yapılan kümeleme analizinde ise 3 ayrı küme oluşmuştur. Sonuç olarak bölgedeki asma biyoçeşitliliğinin moleküler karakterizasyonunun tanımlanması ileride yapılacak ıslah çalışmaları ve moleküler çalışmalarda genotiplerin belirlenmesi için bir referans niteliğindedir. Bu çalışmanın sonucunda elde edilmiş bulgular ile bölgesel kültür asma çeşitlerinin geliştirilmesi adına pratikte yararlı olacaktır. Öte yandan ileride SSR belirteçleri ile yapılacak diğer çalışmalar ile de karşılaştırılabilecektir.
\end{abstract}

Anahtar Kelimeler: Vitis vinifera L., SSR, Moleküler Karakterizasyon, Biyoçeşitlilik, Ganos Dağları, Trakya.

\begin{abstract}
This study was carried out to determine the molecular and morphological characterization of the populations of Vitis vinifera L. grapevine forms which have been adapted to the natural flora of the Trakya Region in Ganos (Işılar) Mountains. Materials were collected from 7 different areas on the northern and southern slopes of the mountains between 2014 and 2016 (May, June and July) used for DNA isolation. In 2014 year, 103 samples were taken from surveys. Molecular characterization was carried out in 2016 year on 34 samples were used which have grape clusters. It has been determined that genotypes are different from each other in terms of ampelographic and molecular properties and basis 5 different clusters. In the molecular characterization of 34 genotypes, it performed on the two basic components, there were 3 different clusters formed in terms of clustering analysis. As a result, grapevine biodiversity with molecular characterization in the region is defined. This will be a reference for the further grapevine breeding studies, and also the identification of genotypes. It will be opportunity to practical use in the future for growing regional cultivars. On the other hand these findings will be used as a reference to comparison with SSR marker studies about grape varieties.
\end{abstract}

Keywords: Vitis vinifera L., SSR, Molecular characterization, Bio-diversity, Ganos Mountains, Trakya.

1*Sorumlu Yazar/Corresponding Author: İlknur Korkutal, Namık Kemal Üniversitesi Ziraat Fakültesi Bahçe Bitkileri Bölümü-Tekirdağ. E-mail: ikorkutal@ nku.edu.tr (D) OrcID: 0000-0002-8016-9804

'Elman Bahar. E-mail: ebahar@nku.edu.tr (D) OrcID: 0000-0002-8842-7695

${ }^{1}$ Nihan Şahin, E-mail: nihansahin@nku.edu.tr (i) OrcID: 0000-0002-3204-9082

'Fatma Seren Sağır, E-mail: fssagir@nku.edu.tr (D) OrcID: 0000-0003-2993-2701

'Demir Kök, E-mail: dkok@nku.edu.tr (iD OrcID: 0000-0001-5879-8535

2Onur Ergönül, E-mail: onur.ergonul@tarim.gov.tr (D OrcID: 0000-0002-2251-426X

${ }^{2}$ Tamer Uysal, E-mail: tamer.uysal@tarim.gov.tr

2Zeliha Orhan Özalp, E-mail: zeliha.orhanozalp@tarim.gov.tr (D) OrcID: 0000-0002-3146-6888

Atıf/Citation: Bahar, E., Korkutal, İ., Şahin, N., Sağır, F.S., Kök, D., Ergönül, O., Uysal, T., Özalp, Z.O. Ganos Dağları doğal florasında bulunan kültür asmalarının (Vitis vinifera L.) moleküler ve ampelografik karakterizasyonu. Tekirdağ Ziraat Fakültesi Dergisi, 16(1), 92-102.

CBu çalışma Tekirdağ Namık Kemal Üniversitesi tarafından Creative Commons Lisansı (https://creativecommons.org/licenses/by-nc/4.0/) kapsamında yayınlanmıștır. Tekirdağ 2019 


\section{Extended Summary}

Previous research the morphological description of the grapevine genetic biodiversity in the Ganos Mountains (Northwest of Turkey - Trakya Region) was made; however, it has not been identified by the molecular markers. This study was carried out to determine the molecular and morphological characterization of the populations of Vitis vinifera L. grapevine forms which have been adapted to the natural flora of the Trakya Region in Ganos (Işıklar) Mountains, Turkey.

Materials were collected from 7 different areas on the northern and southern slopes of the Ganos Mountains between 2014 and 2016 (May, June and July) used for DNA isolation. DNA isolation procedures Doyle and Doyle (1987) CTAB protocol was modified. UV gel imaging system and gel images were taken with GelAnaylzer 2010a, afterwards, the score tables were created by using these sizes. 24 genotypes collected from the region (A1, A2, A3, A4, A5, A6, A7, A8, A9, A10, A11, A12, A13, A14, A15, A16, A17, A18, A19, A20, A21, A22, A23, A24) and some leaf and shoot characteristics were examined according to the OIV 2009 criteria (OIV.68, OIV.601, OIV.602, OIV.603, OIV.604, OIV.066-5, OIV.605, OIV.606, OIV.070, OIV.076, OIV.612, OIV.614, OIV.613, OIV.615, OIV.81, OIV.083-1, OIV.083-2, OIV.84). In 2014 year, 103 samples were taken from surveys. Molecular characterization was carried out in 2016 year on 34 samples were used which have grape clusters.

It has been determined that genotypes are different from each other in terms of ampelographic and molecular properties and basis 5 different clusters. In the molecular characterization of 34 genotypes, it performed on the two basic components, there were 3 different clusters formed in terms of clustering analysis. As a result, grapevine biodiversity with molecular characterization in the region is defined.

This will be a reference for the further grapevine breeding studies, and also the identification of genotypes. It will be opportunity to practical use in the future for growing regional cultivars. On the other hand these findings will be used as a reference to comparison with SSR marker studies about grape varieties 
Kültür asmasının (Vitis vinifera L.) anavatanı Anadolu-Kafkasya olup, MÖ 3500'lü yılların öncesine dayanan köklü bir tarihsel geçmişe sahip olup dünyada yetiştirilen birçok üzüm çeşidinin kökeni bu bölgeye dayanmaktadır (Winkler 1962). Trakya bölgesi ve dolayısıyla Ganos Dağları da MÖ 2000 yıllarına kadar uzanan bağcılık kültürüne sahiptir ve doğal melezlerin yayılma alanıdır (Çelik 2011).

Asmaların tanımlanması ile ilgili çalışmalar 19. yüzyılda ampelografik yönteme dayanırken günümüzde bu yöntemlerin yanında DNA belirteçleri kullanılmaya başlanmıştır.

Tekirdağ Bağcılık Araştırma Enstitüsü, ülkemiz genelinden yaklaşık 1436 çeşit toplayarak asma genetik potansiyelinin tanımlanması ve korunması amacı ile Milli Koleksiyon Bağı oluşturmuştur. Ampelografik çalışmaların tamamlandığı bu koleksiyonda farklı veya benzer morfolojik özelliklere sahip ancak aynı isimle adlandırılan çeşit grupları (homonim ve sinonim) ile karşılaşılmaktadır (Yıldırım 2010).

Asmada ilk DNA testleri CSIRO’ da 1990’lı yıllarda, DNA parmak izi tanımlama ile yapılmıştır. Bu teknoloji günümüzde daha geliştirilmiş ve alınan herhangi bir asma dokusundan kısa sürede tanımlama yapılabilmektedir. OIV tarafindan Descriptor List for Grape Varieties and Vitis Species listesinin ikinci sürümünde ampelografik niteliklerin yanı sıra izoenzim karakteristikleri ve fitopatolojik özellikler de eklenmiştir (Tassie 2010). Asmada kullanılan moleküler belirteçlerin en önemlileri SSR belirteçlerdir (Yıldırım 2010). Çeşit tanımlama amaçlı uygulamalar, cins, tür ve çeşitler arasında farklılık (polimorfizm) gösterecek belirteçlerden yararlanılarak, gen kaynaklarının tanımlanabilmesini ve sınıflandırılabilmesini gerçekleştirmektedir (Ağaoğlu ve Ergül 1999).

İlk asma mikrosatellit (SSR) çalışmaları Avusturya'da Thomas ve Scott (1993) tarafından yapılmıştır. Thomas ve ark. (1994) tarafından yürütülen diğer bir çalışmada ise; 5A Teleki ve Kober 5BB anaçlarının SSR analizleri gerçekleştirilmiş, kullanılan belirteçler ile ayrım sağlanamamıştır. Yine Avusturya'da 18 sofralık üzüm çeşidi 11 SSR belirteci ile tanımlanmış, böylelikle genetik belirteçlerin ticari üzüm çeşitlerinde isim doğruluğu tespitinde kullanılabilirliği kanıtlanmıştır (Sefc ve ark. 2009).

Regner ve ark. (2001), Vitis türlerine ait 1200 kadar örneğin genetik tanımlamasını SSR, ISSR, AFLP ve RAPD gibi tekniklerle yapmışlardır. Fossati ve ark. (2001), İtalya Schiave grubuna ait 10 üzüm çeşidinde hem AFLP hem de SSR markörlerle çalışmışlardır. Ülkemizde yapılan bir çalışmada 17 yerli asma kültür çeşidinin genetik tanımlaması RAPD markörleri aracılığı ile gerçekleştirilmiştir. Çalışmada 22 primer kullanılmış, 179 bant amplifiye edilmiş bunlardan 110 tanesinin polimorfik olduğu saptanmıştır (Ergül ve ark. 2002).

Anadolu'da asmanın orijini olduğuna destek olan bir çalışmada (Arroyo-Garcia ve ark. 2006), üzümün iki orjininden birinin Anadolu, diğerinin ise İspanya olduğu tespit edilmiştir. Vouillamoz ve ark. (2006), Türkiye, Gürcistan ve Ermenistan'dan toplanan örneklerde 6 SSR belirteci ile genetik analizler yapmışlar; Türkiye'deki çeşitler ile dünya çapında tanınmış diğer çeşitler arasında sinonim ilişkisini araştırmış buna göre, İridaneli ile Italia, Parmak ile Jerusalem Bleu çeşitlerinin sinonim olabileceğini belirtmişlerdir.

Tangolar ve ark. (2009) çalışmada on dört SSR belirteci kullanmışlardır. Adana ve çevresindeki 59 asma kültür çeşidinde toplam 117 allel tanımlamışlardır. Ortalama allel sayısı 8,357 ve beklenen ve gözlenen heterozigoti oranı; sırasıyla 0,743 ve 0,749 olarak belirlenmiştir. Hızarcı ve ark. (2012) Kuzeydoğu Anadolu'daki Yusufeli bölgesinde bulunan 27 asma kültür çeşidinde yaptıkları çalışmada 6 farklı SSR belirteci kullanarak genetik karakterizasyonu ve 2 kültür çeşidi (Cabernet-Sauvignon ve Merlot) ile parmak izi belirleme çalışması yapmışlardır. Çalışmanın sonucunda toplam 52 allel belirlenmiştir ve her lokus başına ortalama allel değeri 8,670 olarak bulunmuştur.

Ülkemize ait bazı üzüm çeşitlerinin RAPD markörler kullanarak tanımlamaları Ergül ve ark. (2002) tarafından yapılmıştır. Araştırıcılar 17 üzüm çeşidini kullandıkları kümeleme analizi sonucunda iki ana grup belirlemiş̧lerdir. Genetik farklılık ve bölgesel ayrım yaparak 4 grup oluştuğunu; ilk grupta Hafızali, Razakı, Müşküle ve Kadın Parmağı üzüm çeşitlerinin yer aldığını, bu grubun Ege ve Marmara Bölgelerinden geldiğini, Hafızali ile Razakı'nın yüksek benzerlik gösterdiğini saptamışlardır. İkinci gruptaki Hasandede ve Emir çeşitlerinin de benzer olduklarını, ayrıca Kozak beyazı ve Kozak Siyahı'nın da akraba olduğu tespit etmişlerdir. Öküzgözü üzüm çeşidinin Doğu Anadolu, Papazkarası çeşidinin Trakya'da yer alarak yerel genotip olduklarını ifade etmişlerdir.

Tekirdağ Bağcılık Araştırma Enstitüsü Milli Koleksiyon Bağı'nda bulunan; Güneydoğu Anadolu orijinli 55 (Vitis vinifera L.) üzüm çeşidini SSR markörleri kullanarak tanımlayan Boz ve ark. (2011), yaptıkları araştırmada Cabernet-Sauvignon, Merlot ve Pinot Noir çeşitleri referans olarak kullanmışlardır. Araştırıcılar SSR yönteminin diğer tanımlama yöntemlerinden daha avantajlı ve 14 SSR markörünün çeşit-klon tanımlamada ve ayrıca akrabalık analizinde daha etkin olduğunu belirtmişlerdir. Ayrıca, sinonim ve homonim olan çeşitleri de ortaya koyarak; ülkemizde homonim çeşitlerin sayısının çok olduğunu ifade etmişlerdir. 
Karataş ve ark. (2014) Türkiye'nin Güneydoğu Anadolu Bölgesi’nde bulunan yabani ve kültüre alınmış asmaların genetik çeşitliliğinin belirlenmesi amacıyla yürüttükleri bir çalışmada 21 yabani ve 13 kültür asmasının sürgün ucu örneklerinden DNA analizi yapmışlardır. Yabani asmalardan alınan yaprak ve çiçek örneklerinin ampelografik tanımlamaları sonucu Vitis sylvestris ile birçok benzer morfolojik özellik gösterdiğini belirlemişlerdir. Vitis sylvestris'in kültür asmalarıyla melezlenmesi ile çok geniş alanlara yayıldı̆̆ı; bunun da çoğunlukla kuşlar nedeniyle olduğunu ifade etmişlerdir. Araştırıcılar nSSR ve cpSSR markörlerinin kültür ve yabani asmalarda genetik farklılıkların ortaya konmasında ve akrabalık seviyelerinin belirlenmesinde kullanışlı olduğunu saptamışlardır.

Ganos Dağları'nda bulunan asma genetik biyoçeşitliliğinin daha önce NKÜ.BAP.00.24.AR.14.18 nolu proje kapsamında 2014 yılında alınan örnekler ile morfolojik tanımlaması yapılmış; ancak moleküler belirteçler ile tanımlanması yapılmamıştır. Bu çalışma, Trakya Bölgesi Ganos (Işıklar) Dağları doğal florasına adapte olmuş ve varlığını sürdüren Vitis vinifera L. asma formlarına ait popülasyonların ileride yapılabilecek ıslah çalışmaları için tespiti ve bunlardan elde edilen materyallerin önce morfolojik; sonrasında moleküler belirteçler (SSR) ile genetik karakterizasyonlarının belirlenmesi amacıyla yapılmıştır.

\section{Materyal ve Konum}

\section{Materyal ve Yöntem}

Ganos Dağı doğal florasında Vitis vinifera L.' ya ait birçok asma yetişmektedir. Tekirdağ ili sınırları içinde yer alan Ganos Dağı'nın diğer bir ismi de Işıklar Dağı'dır. Bu dağ Şarköy ilçe sınırları ile ilimize adını veren Tekir Dağları'nın en yüksek (945m) yeridir. Dağ ikinci jeolojik zamanda Kuzey Anadolu dağ kuşağı içinde yer alır. Dağ, adını Ksenofon' un Trak kralı Seuthes'e ait kıyı şehri olduğunu yazdığı ve bugün Gaziköy sınırlarında yer alan antik Ganos yerleşim yerinden almaktadır.

\section{Sörvey Çalışmaları}

Sörvey ve örnek toplama çalışmalarında Bitki Genetik Kaynaklarının standart toplama formatları kullanılmışıtır. Örnek toplamada üç farklı yol izlenmiştir;

* Arkeolojik çalışmalar sonucu belirlenmiş olan eski uygarlıkların yerleşim alanları [Iş̧ılar Eski Kilise, Sütlüce Manastırı, Bilinmeyen Kilise, Heraion Teikhos, Hieron Oros (Kartalkaya), Kaletepe, Güzelköy (Melen) Manastır mevkii, vb.] veya yakınlarında inceleme yapılmış ve bulunan örnekler alınmıştır (Karataş ve ark. 2014).

* Köylerde yaşayanların bilip tespit ettikleri (Hoşköy, Gaziköy, Işıklar, vb.) asmalardan örnek alınmıştır.

* Asma bulunması ihtimali yüksek olan bölge ve dere yataklarından (Çitlenbik deresi, Gübürlük deresi, Polatandere, Mermer deresi, Menekşe deresi, Kavaklar deresi, Karadere, Ayvasıl deresi, Uçmakdere, Çınarlıdere, vb.) aramak suretiyle örnekler toplanmıştır (Şekil 1).
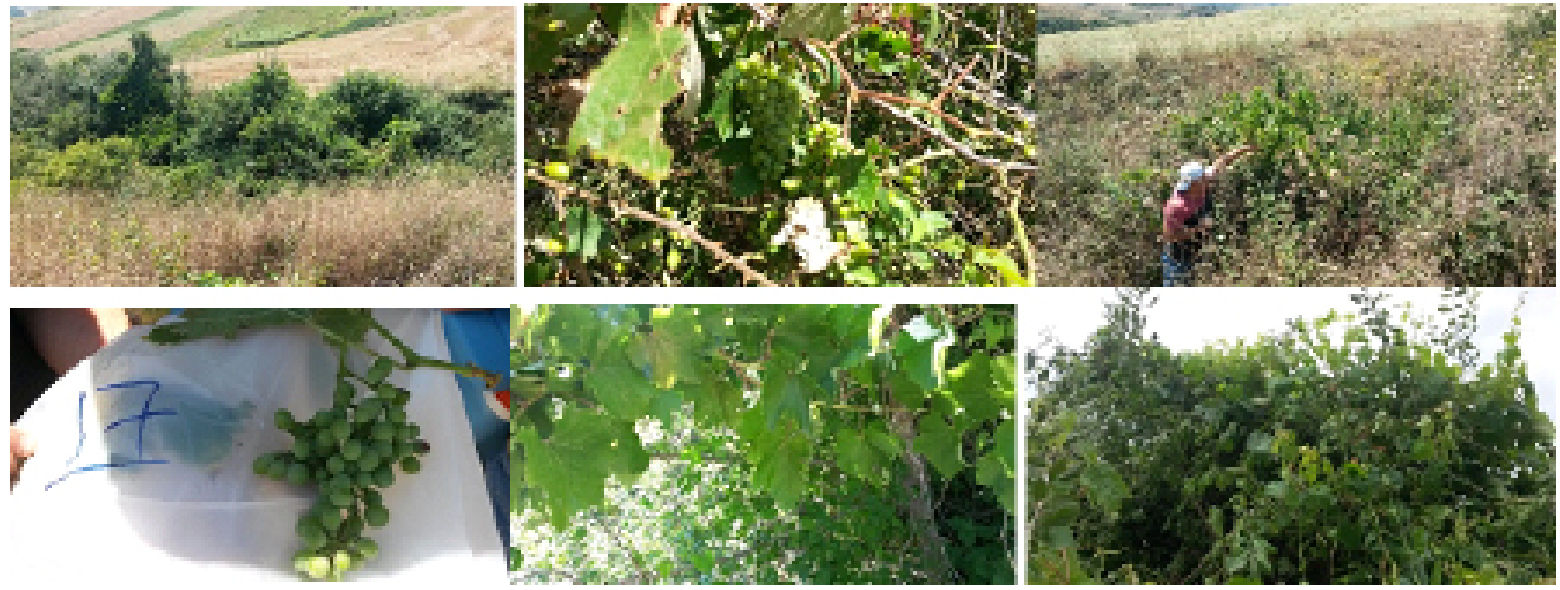

Şekil 1. Örnek toplama çalışmaları

Figure 1. Collecting grapevine samples

2014 yılında yapılmış olan sörvey çalışmalarında belirlenen 103 örnekten salkım gösteren 34 tanesinden 2016 yılında materyal alınmış ve 6 SSR belirteci kullanılarak moleküler karakterizasyonları yapılmıştır. Elde edilen 24 genetik materyalde, 18 ampelografik karakter OIV (2009)'e göre incelenmiştir. 


\section{Moleküler Karakterizasyon}

DNA izolasyon işlemleri Doyle ve Doyle (1987) CTAB protokolü modifiye edilerek yapılmıştır. Ayrıca bazı örneklerdeki kalıntıların temizlenmesi için fenolle yıkama prosedürü uygulanmıştır (Moore ve Dowhan 2002). DNA izolasyonları sonrasında PCR amplifikasyonları için OIV tarafından önerilen VVMD5, VVMD6, VVMD7, VVMD8, VrZAG79, VrZAG67 (Bowers ve ark. 1996, Sefc ve ark. 1999) SSR primerleri kullanılmıştır. PCR koşulları Bowers ve ark. (1996) ve Sefc ve ark. (1999)'de bildirildiği gibi ayarlanmıştır. PCR işlemleri sonrasında elektroforez işlemleri $\% 10 \mu \mathrm{l} / \mathrm{ml}(\mathrm{v} / \mathrm{v})$ etidyum bromit ile boyanmış \%2'lik agaroz jelde 130 Voltta 35 dakika yürütüldükten sonra UV jel görüntüleme sistemi ile görüntülenmiştir. Görüntüsü alınan jel fotoğrafları GelAnaylzer 2010a ile incelenerek DNA bant büyüklükleri belirlenmiş, daha sonra bu büyüklüklerden faydalanılarak skor tabloları oluşturulmuştur.

\section{Morfolojik Karakterizasyon}

Bölgeden toplanan 24 genotipte (A1, A2, A3, A4, A5, A6, A7, A8, A9, A10, A11, A12, A13, A14, A15, A16, A17, A18, A19, A20, A21, A22, A23, A24) baz1 yaprak ve sürgün özellikleri incelenmiştir (OIV.68, OIV.601, OIV.602, OIV.603, OIV.604, OIV.066-5, OIV.605, OIV.606, OIV.070, OIV.076, OIV.612, OIV.614, OIV.613, OIV.615, OIV.81, OIV.083-1, OIV.083-2, OIV.84) (OIV 2009).

\section{İstatistiki Analiz}

Kümeleme analizi Ward metodu (en küçük varyans) ile R istatistik programı (3.3.2 Sincere Pumpkin Patch) kullanılarak yapılmıştır. Temel bileşenler analizi (PCA) yine R istatistik programında FactoMiner kütüphanesi kullanılarak yapılmıştır (Husson ve ark. 2010). Aynı analizler SPSS-PASW Statistics 18 paket programı ile tekrarlanmıştır.

\section{Bulgular ve Tartışma}

Çalışmada kullanılan altı belirteç toplam 17 farklı allel üretmiştir. Altı belirteç için yapılan temel bileşenler analizinde iki önemli bileşenin ortaya çıktığı ve bu iki temel bileşenin genotipler arasındaki toplam varyasyonun \%38,796'sını içerdiği görülmüştür (Çizelge 1). Birinci temel bileşen için en yüksek etkinliğin VVMD6 belirtecinin 1. ve 3. allelinde, VVMD7 belirtecinin 1. ve 3. allelinde ve VVMD8 belirtecinin 2 ve 3. allellerinde olduğu görülmüştür. İkinci temel bileşen için en yüksek etkinlikler ise VVMD5 ve VVMD7 belirteçlerinin tüm allellerinde olmuştur.

Şekil 2'de incelenen 34 genotipin üç ana kümede toplandığı görülmektedir. Oluşan ilk kümede A3, A4, A5, A9, A12, A22, A23 ve A28 genotipleri yer almaktadır, İkinci kümede ise A2, A6, A7, A10, A13, A14, A16, A18, A19, A20, A21, A24, A26, A27, A29, A30, A31, A32 ve A34 olmak üzere 19 genotip yer almıştır. Diğer iki kümeden tamamen bağımsız olan, üçüncü ve son kümede ise A1, A8, A11, A15, A17, A25 ve A33 genotipleri yer almıştır. Faktör ve kümeleme haritalarında benzer şekilde, kümeleme analizinde de genotipler aynı gruplar içerisinde yer almıştır.

Çizelge 1. Altı belirteç için iki temel bileşen değerleri (L1: Lokus 1; L2: Lokus 2; L3: Lokus3; L4: Lokus 4; L5: Lokus 5; L6: Lokus 6; A1: Allel 1; A2: Allel 2; A3: Allel 3, PIC: Polimorfik Bilgi İçeriği)

Table 1. Two principle components for six markers (L1: Locus 1; L2: Locus 2; L3: Locus3; L4: Locus 4; L5: Locus 5; L6: Locus 6; A1: Allel 1; A2: Allel 2 2; A3: Allel 3, PIC: Polymorphic Information Content)

\begin{tabular}{|c|c|c|c|c|}
\hline \multirow{2}{*}{ Belirteç } & \multirow{2}{*}{ Allel } & \multicolumn{2}{|c|}{ Temel Bileşen Katkısı } & \multirow{2}{*}{$\mathrm{PIC}$} \\
\hline & & Bileşen 1 & Bileşen 2 & \\
\hline \multirow{2}{*}{ VVMD5 (L1) } & A1 & 0,061 & 27,317 & 0.3893 \\
\hline & A2 & 0,012 & 18,688 & 0.3270 \\
\hline \multirow{3}{*}{ VVMD6 (L2) } & A1 & 16,585 & 0,269 & 0.2907 \\
\hline & A2 & 1,114 & 1,857 & 0.1107 \\
\hline & A3 & 9,760 & 0,843 & 0.1107 \\
\hline \multirow{3}{*}{ VVMD7 (L3) } & A1 & 14,650 & 1,052 & 0.2509 \\
\hline & A2 & 4,361 & 3,864 & 0.4931 \\
\hline & A3 & 13,937 & 0,731 & 0.3270 \\
\hline \multirow{3}{*}{ VVMD8 (L4) } & A1 & 0,467 & 0,039 & 0.1107 \\
\hline & $\mathrm{A} 2$ & 16,447 & 1,061 & 0.2907 \\
\hline & A3 & 18,427 & 1,100 & 0.2509 \\
\hline
\end{tabular}


(Çizelge 1 devami)

\begin{tabular}{ccccc}
\hline & A1 & 0,450 & 2,395 & 0.2076 \\
\cline { 2 - 5 } & A2 & 0,079 & 3,239 & 0.2076 \\
\cline { 2 - 5 } VrZAG64 (L5) & A3 & 0,627 & 2,308 & 0.2907 \\
\cline { 2 - 5 } & A4 & 0,881 & 0,011 & 0.1107 \\
\hline \multirow{2}{*}{ VrZAG79 (L6) } & A1 & 2,091 & 17,067 & 0.3893 \\
\hline Eigen Değerleri & A2 & 0,043 & 18,149 & 0.2907 \\
\hline \% Varyans & & 4,209 & 2,386 & \\
\hline \%Kümülatif Varyans & & 24,758 & 14,037 & \\
\hline
\end{tabular}

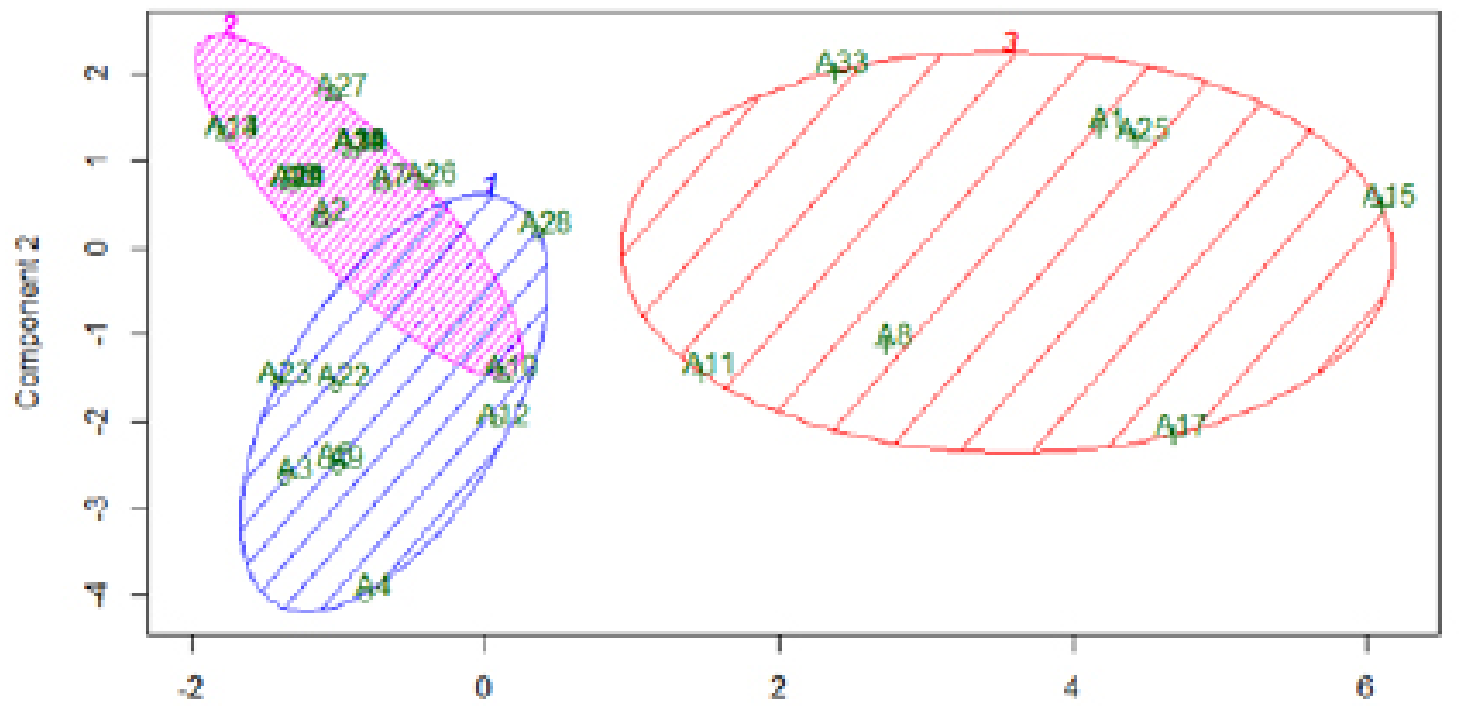

Component 1

These two components explain $38.8 \%$ of the point variabily.

Şekil 2. İncelenen 34 genotipin iki temel bileşene göre kümeleme haritası

Figure 2. Factor map of examined 34 genotypes according to two principle components

Morfolojik bulgulara göre yapılan PCA sonucunda iki önemli bileşen ortaya çıkmış ve bu iki bileşenin toplam varyasyonun \%54,99’unu açıkladığı görülmüştür (Çizelge 2). \%41,90 toplam varyasyonu içeren ilk bileşen grubunda en yüksek etkinliğe sahip karakterler OIV.602, OIV.603 ve OIV.614 olurken, toplam varyansın \%13,20'sini içeren ikinci bileşen grubunda en yüksek etkinliğin OIV.066-5, OIV.613 ve OIV.604 karakterlerinde olduğu görülmüştür.

Çizelge 2. Yirmidört genotipte incelenen ampelografik özellikler için temel bileşen değerleri

Table 2. Ampelographic characteristics of 24 genotypes' principle component values

\begin{tabular}{|c|c|c|}
\hline \multirow{2}{*}{ Karakter } & \multicolumn{2}{|c|}{ Temel Bileşen Katkısı } \\
\hline & Bileşen 1 & Bileşen 2 \\
\hline OIV.68 & 0,896 & 1,062 \\
\hline OIV.601 & 0,896 & 2,029 \\
\hline OIV.602 & 11,720 & 1,931 \\
\hline OIV.603 & 10,948 & 4,802 \\
\hline OIV.604 & 6,672 & 5,681 \\
\hline OIV.066-5 & 8,296 & 9,478 \\
\hline OIV.605 & 8,485 & 4,173 \\
\hline OIV.606 & 8,325 & 5,256 \\
\hline OIV.070 & 0,027 & 4,539 \\
\hline
\end{tabular}


(Çizelge 2 devamı)

\begin{tabular}{ccc}
\hline OIV.076 & 0,421 & 1,871 \\
\hline OIV.612 & 7,563 & 2,797 \\
\hline OIV.614 & 10,747 & 4,445 \\
\hline OIV.613 & 5,857 & 6,471 \\
\hline OIV.615 & 6,541 & 4,228 \\
\hline OIV.81 & 0,585 & 3,132 \\
\hline OIV.083-1 & 1,573 & 1,290 \\
\hline OIV.083-2 & 0,163 & 1,797 \\
\hline OIV.84 & 0,448 & 4,105 \\
\hline Eigen Değerleri & 7,523 & 2,376 \\
\hline \% Varyans & 41,794 & 13,202 \\
\hline \%ümülatif Varyans & 41,794 & 54,997 \\
\hline
\end{tabular}

Değişkenlere ait faktör haritası incelendiğinde; karakterlerin haritanın dört bölümünde de bulunduğu görülmektedir (Şekil 3). Her iki bileșen açısından da pozitif olan ilk grupta OIV.083.2, OIV.605, OIV.606, OIV.066.5, OIV.601, OIV.602, OIV.603 ve OIV.604 karakterleri yer almaktadır. Bu karakterlerin tümü her iki bileşen için de pozitif etkili olmuştur. Birinci bileşen için pozitif, ikinci bileşen için negatif olan ikinci grupta OIV.614, OIV.613, OIV.612, OIV.615, OIV.68 ve OIV.81 karakterleri yer almaktadır. Bu karakterlerin birinci bileşene katkıları pozitif olurken, ikinci bileşen açısından negatif etkili olmuşlardır. Birinci bileşen açısından negatif, ikinci bileşen açısından pozitif olan diğer üçüncü grupta OIV.83.1, OIV.76.1 ve OIV.70.1 karakterleri yer almıştır. Her iki bileşen için negatif olan dördüncü grupta ise OIV.84 karakteri tek başına yer almıştır.

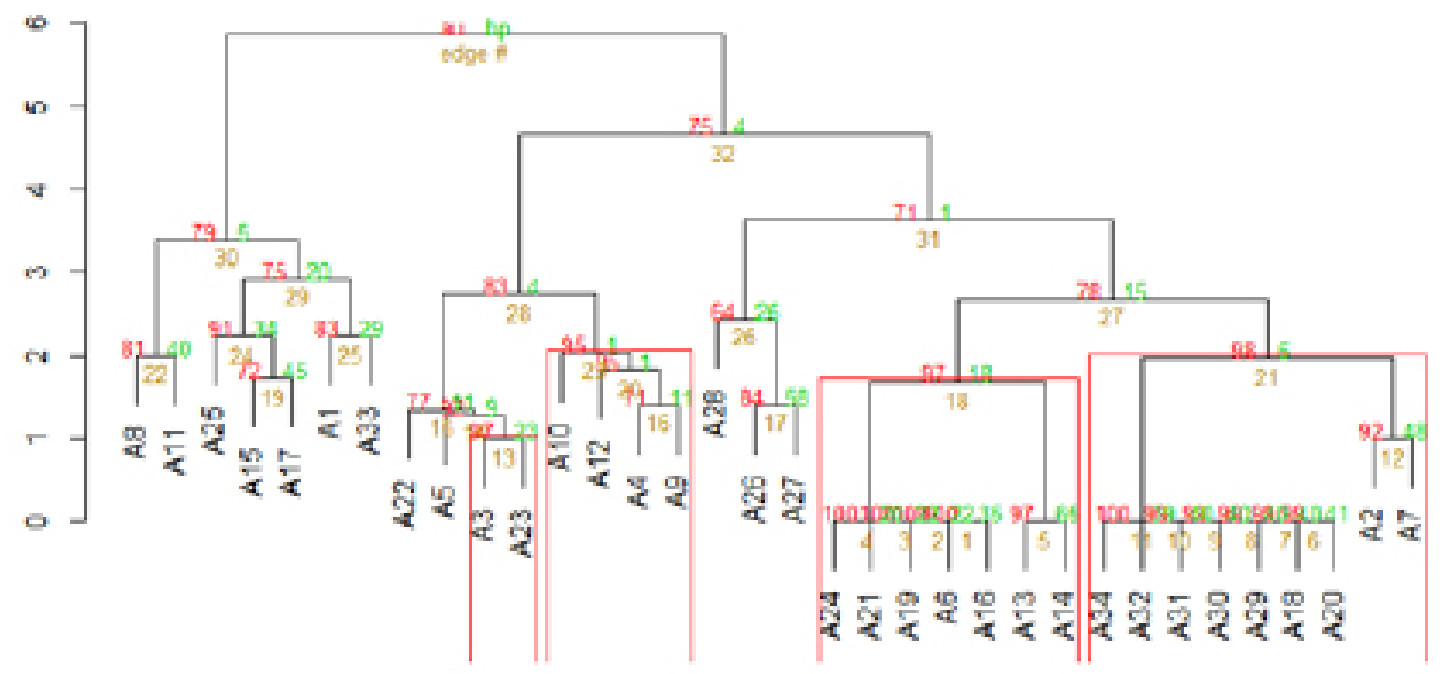

Component 1

These two components explain $38.8 \%$ of the point variabity.

Şekil 3. İncelenen 34 genotipin kümeleme analizi dendogramı

Figure 3. Cluster analysis dendogram of 34 genotypes

İki temel bileşen göz önüne alınıp kümeleme analizi yapıldığında incelenen 24 genotipin 5 kümeye ayrıldığ Şekil 4'de görülmektedir. Birinci kümede A17, A9, A12, A1, A16, A20 ve A21 yer almıştır. İkinci kümede A21, A19, A13, A10, A6, A5, A14 ve A7 yer almıștır. A21 genotipinin her iki kümenin kesiştiği alanda yer aldığ görülmüştür. Üçüncü küme tüm diğer kümelerden uzakta A15 ve A8 genotiplerini içermektedir. Dördüncü kümede A22, A18, A23 ve A24 genotipleri yer alırken, beşinci kümede A2, A4, A11 ve A3 genotipleri yer almıştır. 


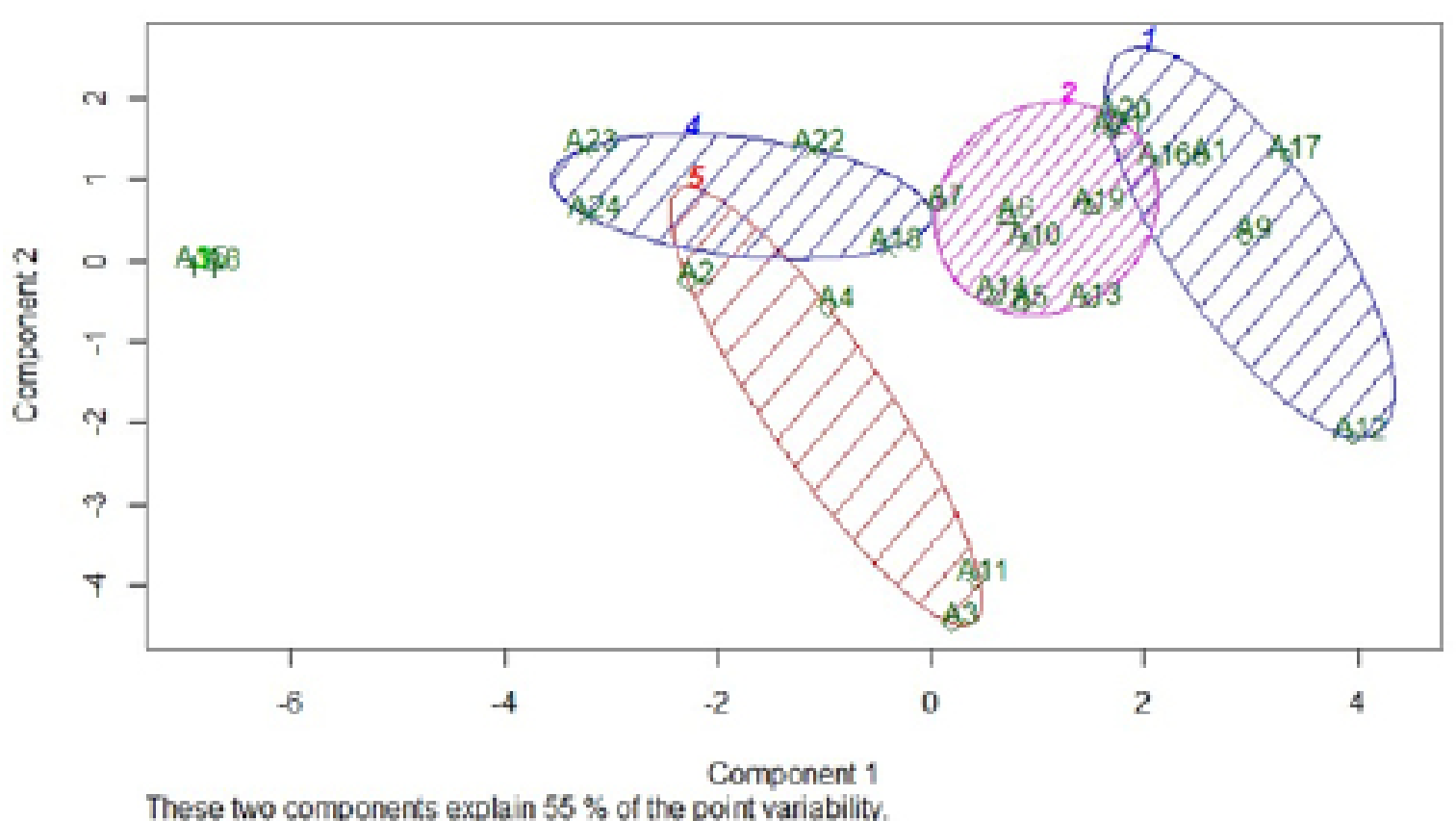

Şekil 4. Yirmidört genotipin 18 ampelografik (OIV) karaktere bağlı olarak iki temel bileşene göre kümeleme analizi grafiği

Figure 4. Two principle components cluster analysis map of 24 genotypes according to the 18 ampelographic characters (OIV)

İncelenen genotiplerin kümeleme analizi dendogramı Şekil 5'de verilmiştir. Dendogram incelendiğinde genotiplerin iki ana küme altında gruplandığı görülmektedir. İlk kümede temel bileşenler analizinde de olduğu gibi A8 ve A15 genotipleri yer almakta, diğer tüm genotipler ikinci ana kümede yer almıştır.

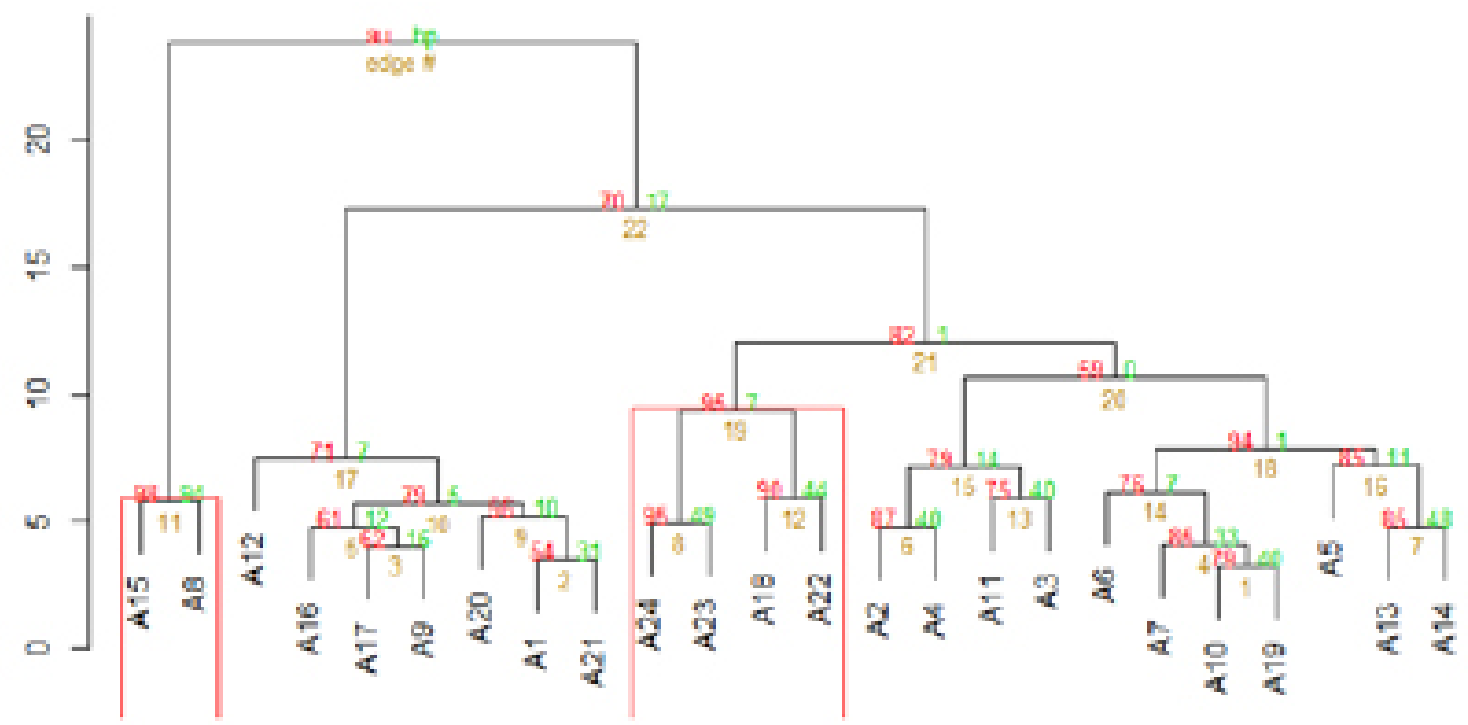

Şekil 5. İncelenen 24 genotipin 18 ampelografik (OIV) karaktere göre kümeleme analizi dendogramı

Figure 5. Cluster analysis dendogram of examined 24 genotypes according to the 18 ampelographic characteristics (OIV)

Oluşan ikinci ana küme de kendi içerisinde iki alt gruba ayrılmış, ilk alt grupta A12, A16, A17, A9, A20, A1 ve A21 yer almıştır. İkinci alt grupta ise A23, A24, A18, A22, A2, A4, A11, A3, A6, A7, A10, A19, A5, A13 ve A14 genotipleri yer almıştır. Dolayısıyla OIV'ye ait 18 ampelografik karaktere göre A8 ve A15 genotiplerinin birbirleriyle çok benzer bireyler olduğunu söylemek mümkün gözükmektedir. Ayrıca A24 ile A23 ve A18 ile A22 genotipleri de birbirlerine çok yakındır. Ayrı bir grup oluşturan A12, A16, A17, A9, A20, A1 ve A21 genotiplerinin içerisinde A12 genotipi tek başına yer alırken, A17 ve A9 yakın, A16 ise onlarla yakın ilişkili olarak görülmektedir. 
$\mathrm{Bu}$ grup içerisindeki A1 ile A21 yine birbirine yakın genotipler olarak gözükmekteyken A20 genotipinin de bunlarla yakın ilişkili olduğu anlaşılmaktadır.

A2, A4, A11, A3, A6, A7, A10, A19, A5, A13 ve A14 genotiplerinin oluşturduğu diğer bir grupta A2 ile A4 ve A11 ile A3 genotiplerinin birbirleriyle çok benzer ve iki grubun birbiriyle yakın ilişkili oldukları görülmektedir. A6, A7, A10 ve A19 genotipleri arasındaki ilişki A13, A14 ve A15 arasındaki ilişkiye benzer șekildedir. A13 ve A14 birbiriyle çok yakın ilişkili ve A15 genotipinin de bunlarla bağlantılı olduğu saptanmıştır. Tüm genotipler içerisinde A8 ile 15 genotiplerinin oluşturduğu grup ile A13 ve A14 genotiplerinin oluşturduğu grup, birbirleriyle en az ilişkili olmuştur (Şekil 5).

Genotiplerin kendi içlerinde incelendiği moleküler ve ampelografik iki kümeleme analizi (Şekil 3 ve Şekil 5) karşılaştırıldığında; genotipler benzer dağılımlar göstermiştir. Ampelografik verilere göre yapılan kümeleme analizinde (Șekil 3) ilk küme içerisinde yer alan A8 ve A15, moleküler verilere göre yapılan ikinci kümelemede de ilk küme içerisinde yer almış, bu iki genotipe ek olarak, ampelografik analizde ikinci küme içerisinde yer alan A1, A11, A17 ve moleküler analizde dahil edilen A25 ve A33 genotipleri de bu küme içerisinde yer almıştır. A22, A5, A3, A23, A10, A12, A4, A9, A24, A21, A19, A6, A16, A13, A14, A18, A20, A2, A7 her iki analizde de ikinci küme içerisinde bulunmuştur. Moleküler kümeleme analizinde ilk defa eklenen A28, A26, A27, A34, A32, A31, A30 ve A29 genotiplerinin de ikinci küme içerisinde yer aldığı görülmüştür. Her iki dendogram incelendiğinde A13 ve A14 genotipleri beraber dağılmıştır. Buna ek olarak A8 ve A15; A12 ve A9; A6 ve A19 genotipleri de her iki dendogramda birbirine oldukça yakın dağılım göstermiştir.

\section{Sonuç}

Bu çalışmada, Trakya bölgesinde yer alan Ganos (Işıklar) Dağları doğal florasında bulunan asmalardan (Vitis vinifera L.) 34 genetik materyal toplanmıştır. Ampelografik ölçümlerle bu asmaların sürgün ucu, genç yaprak ve olgun yaprak özellikleri belirlenirken, DNA'ları izole edilerek 6 belirteç (VVMD5, VVMD6, VVMD7, VVMD8, VrZAG64, VrZAG79) ile moleküler karakterizasyonları yapılmıştır. Örnekler; Karaevli altı, Kumbağ, Naip-Işıklar arası, Mermer-Yeniköy arası, Uçmakdere köyü, Gaziköy, Hoşköy-Mürefte-Şarköy hattı olmak üzere 7 farklı alandan toplanmıştır. Çalışma sonucunda:

Elde edilen genetik materyallerden 24 tanesi 18 ampelografik karakter açısından karşılaştııılmıştır ve bunun sonucunda 5 ayrı küme oluşmuştur. Ayrıca 34 genotipin moleküler olarak iki temel bileşene göre yapılan kümeleme haritasında ise 3 ayrı küme oluşmuştur.

Ampelografik karşılaştırmada birbirlerine çok yakın ilişsili olarak bulunan A13 ve A14 genotipleri, moleküler karakterizasyonlar sonucunda da aynı kolda ve birbirlerine yakın olarak bulunmuşlardır. Benzer şekilde A8 ve A15, A12 ve A9, A6 ve A19 genotipleri her iki dendogramda da birbirlerine oldukça yakın dağılım göstermiştir.

Doğal florada nispeten dar bir çevrede olmalarına rağmen çalışmada yer alan genotiplerin hem ampelografik hem moleküler incelemeler sonucunda çoğunlukla birbirlerinden farklı oldukları saptanmıştır. Ampelografik ölçümlerin sonucunda birbirleriyle tamamen aynı olan hiçbir genotipe rastlanmazken, moleküler karakterizasyonda incelenen lokuslar bakımından A31, A32, A30, A29, A18 ve A20 genotiplerinin ve A19, A21, A6 ve A16 genotiplerinin birbirleriyle tamamen aynı olduğu tespit edilmiştir. Dolayısıyla aynı bölgeden alınan genotiplerin ampelografik ve genetik olarak farklı özellikler gösterebildiği ve farklı bölgelerden toplanan bazı genotiplerin de birbirleriyle benzer özellikler taşıdığı anlaşılmıştır.

MÖ 2000 yıllarına dayanan geçmişe ve genetik çeşitliliğe sahip Trakya Bölgesi’nde incelenen genotiplerin kültüre alınarak morfolojik özellikleri ile fenolojik gelişimlerinin gözlenmesi, bölgenin yerel çeşitleriyle (Tekirdağ, Edirne, Kırklareli, Çanakkale çeşitleri) karşılaşıırmalı olarak incelenmeleri, bölgenin asma biyoçeşitlilik haritasının çıkarılması, ekonomik değeri olan yerel çeşitlerimizin tanınması ve geliştirilmesi için faydalı olacaktır.

Sonuç olarak; geniş kapsamlı çalışmalarla bölgeden daha fazla genotip toplanması, ampelografik ve moleküler karakterizasyonlarının yapılması, genetik materyal olarak koleksiyon haline getirilmesi vb. işlemlerin biyolojik çeşitliliğimizin korunması ve gelecekteki ıslah çalışmaları için materyal sağlanması bakımından büyük önem taşıdığı düşünülmektedir.

\section{Teșekkür}

Bu çalı̧̧ma Namık Kemal Üniversitesi Bilimsel Araştırma Projeleri Koordinasyon Birimi tarafindan NKÜ. BAP.00.24.AR.14.19 nolu proje kapsamında desteklenmiştir. 


\section{Kaynakça/References}

Ağaoğlu YS, Ergül A, 1999. Amasya üzüm çeşidi ekotiplerinin RAPD markörler ile genetik tanımlamaları. Türkiye III. Ulusal Bahçe Bitkileri Kongresi, 14-17 Eylül 1999. 369-372. Kizılcahamam, Ankara.

Arroyo-Garcia R, Ruiz-Garcia L, Bolling L, Ocete R, Lopez MA, Arnolda C, Ergül A, Söylemezoğlu G, Uzun Hİ, Cabello F, Ibanez J, Aradhya MK, Atanassov A, Atanassov I, Balint S, Ceniz JL, Constantini L, Goirslavets S, Grando MS, Klein BY, McGovern PE, Merdinoğlu D, Pejic I, Pelsy F, Primikirios N, Risovannaya V, Roubelakis-Angelakis KA, Snoussi H, Sotiri P, Tamhankar S, This P, Troshin L, Malpica JM, Lefort F, Martinez-Zapater JM, 2006. Multiple origins of cultivated grapevine (Vitis vinifera L. ssp. sativa) based on chloroplast DNA Polymorphisms. Molecular Ecology. 15: 3707-3714.

Bowers JE, Dangi GS, Vignani R, Meredith CP, 1996. Isolation and characterization of new polymorphic simple sequence repeats loci in grapevine (Vitis vinifera L.). Genome. 39: 628-633.

Boz Y, Bakır M, Celikkol BP, Kazan K, Yılmaz F, Cakır B, Aslantas S, Söylemezoğlu G, Yasasın AS, Özer C, Celik H, Ergül A, 2011. Genetic characterization of grape (Vitis vinifera L, ) germplasm from Southeast Anatolia by SSR Markers. Vitis. 50(3): 99-106.

Çelik S, 2011. Bağcılık (Ampeloloji), Cilt 1, 3. Baskı, Tekirdağ, 423s.

Doyle JJ, Doyle JL, 1987. A rapid DNA isolation procedure for small quantities of fresh leaf tissue. Phytochemical Bulletin. 19: 11-15.

Ergül A, Marasalı B, Ağaoğlu YS, 2002. Molecular discrimination and identification of some Turkish grape cultivars (Vitis vinifera L.) by RAPD Markers. Vitis. 41(3): 159-160.

Fossati T, Labra M, Castiglione S, Failla O, 2001. The use of AFLP and SSR molecular markers to decipher homonyms and synonyms in grapevine cultivars: the case of the varietal group known as Schiave. Theoretical and Applied Genetics. 102: 200-205.

Hızarcı Y, Ercișli S, Yüksel C, Ergül A, 2012. Genetic characterization and relatedness among autochthonous grapevine cultivars from Northeast Turkey by Simple Sequence Repeats (SSR). Journal of Applied Botany and Food Quality. 85, 224 - 228.

Karataş DD, Karataş H, Laucou V, Sarıkamış G, Riahi L, Bacilieri R, This P, 2014. Genetic diversity of wild and cultivated grapevine accessions from South-East Turkey. Hereditas. 151: 73-80.

Moore DD, Dowhan D, 2002. Preparation and Analysis of DNA. Current Protocols in Molecular Biology. http://dx.doi.org/10.1002/0471142727. $\mathrm{mb} 0200 \mathrm{~s} 58$.

OIV 2009. $2^{\text {nd }}$ Edition of the OIV Descriptor List for Grape Varieties and Vitis species. 178p. Organisation Intergouvernementale cree par l'Accord International du 3 Avril 2001 http://www.oiv.int/oiv/info/ enplubicationoiv\#grape. Erişim Tarihi 24.02.2014.

Regner F, Staldbauer A, Eisenheld C, 2001. Molecular markers for genotyping grapevine and for identifying clones of traditional varieties. International Symposium on Molecular Markers in Horticultural Species, Acta Horticulturae. 859, 546: $331-342$.

Sefc KM, Pejic I, Maletic E, Thomas MR, Lefort F, 2009. Microsatellite markers for grapevine: tools for cultivar identification and pedigree reconstruction, Book chapter of Grapevine molecular Physiology and Biotechnology 565-596. Print ISBN: 978-90-481-2304-9.

Sefc MK, Regner F, Turetschek E, Glössl J, Steinkelher H, 1999. Identification of microsatellite sequences in Vitis riparia and their applicability for genotyping of different Vitis species. Genome. 42:367-373.

Tangolar SG, Soydam S, Bakır M, Karaağaç E, Tangolar S, Ergül A, 2009. Genetic analysis of grapevine cultivars from the Eastern Mediterranean Region of Turkey, based on SSR Markers. Tarım Bilimleri Dergisi. 15(1): 1-8.

Tassie L, 2010. Vine identification - knowing what you have, Australian Government, Grape and Wine Research and Development Corporation. Fact Sheet. August 2010, 8p

Thomas MR, Cain P, Scott NS, 1994. DNA Typing of Grapevines: a universal methodology and database for describing cultivars and evaluating genetic relatedness. Plant Molecular Biology. 25: 939-949.

Thomas MR, Scott NS, 1993. Microsatellite repeats in grapevine reveal DNA polymorphisms when analysed as Sequence Tagged Sites (STSs). Theoretical and Applied Genetics. 86: 985-990.

Vouillamoz JF, McGovern PE, Ergul A, Söylemezoğlu G, Tevzadze G, Meredeith CP, Grando MS, 2006. Genetic characterization and relationships of traditional grape cultivars from Transcaucasia and Anatolia. Plant Genetic Resources. 4(2): $144-158$.

Winkler AJ, 1962. General Viticulture. University of California Press, Berkeley.

Yıldırım N, 2010. Kara (Siyah) üzüm gruplarının SSR (Simple Sequence Repeat) Markörlere dayalı karakterizasyonu ve ülke asma kaynakları ile genetik ilişkisi. Ankara Üniversitesi Biyoteknoloji Enstitüsü. YL Tezi, Ankara, 71s. 


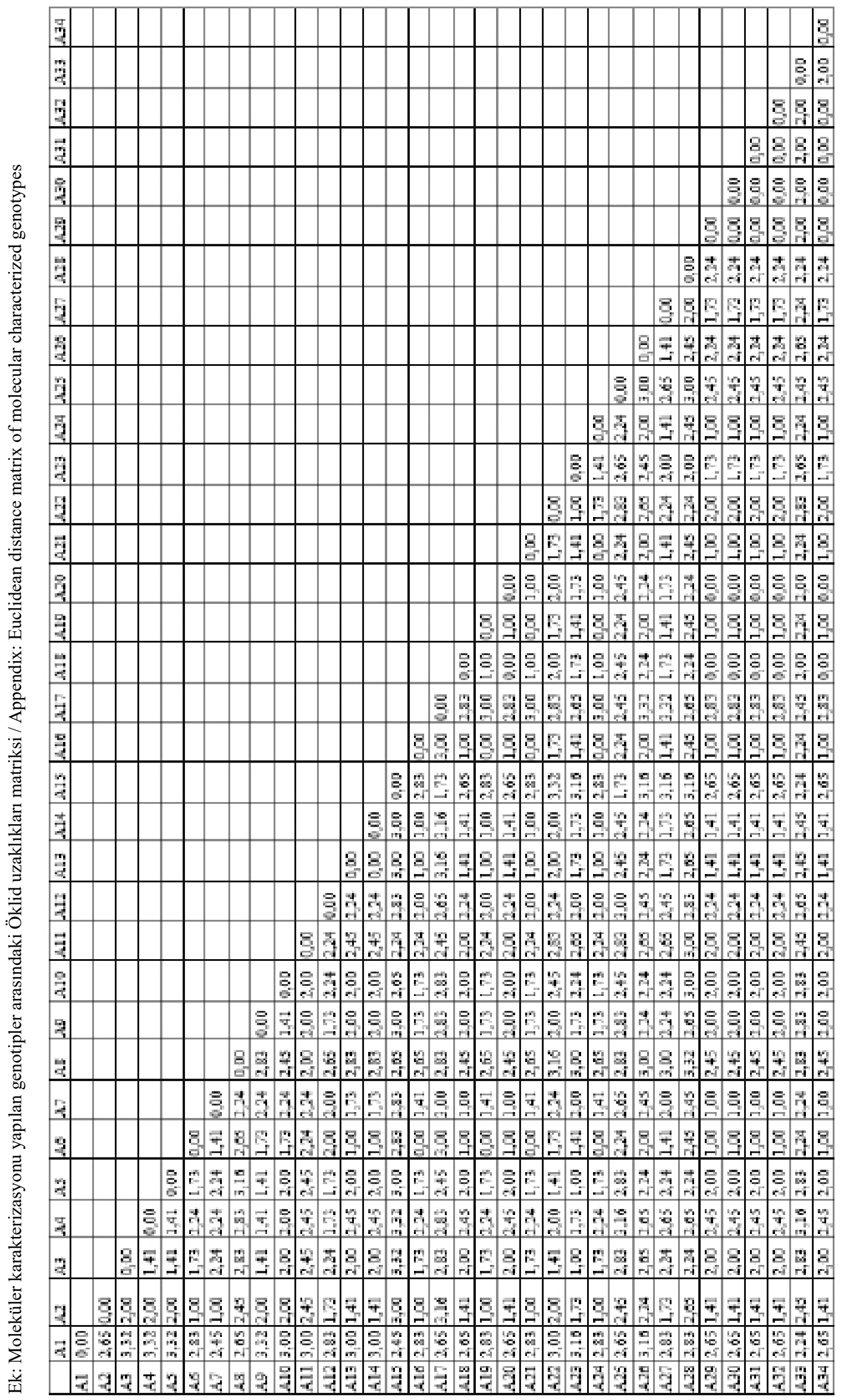

